\title{
Do Context-Rich Lessons Improve Learners' Listening Comprehension Performance?
}

\author{
Nick Morley \\ Astana, Kazakhstan
}

\begin{abstract}
This action research project explores whether context-rich lessons produce better listening comprehension results than context-poor lessons. Video clips and professional quality images improved contextual support to scaffold listening comprehension. Listening segments were adapted from a podcasting site. Fifteen upper intermediate Asian learners participated by completing a pre-study listening skills questionnaire and participating in two context-rich and two context-poor lessons featuring listening texts and comprehension gap-fills. Post-listening questionnaires provided learners' evaluations of their listening experience. A post-project questionnaire surveyed impressions of the two lesson types. Outcomes from context-rich lessons were compared with contextpoor lessons by correlating learners' post-listening questionnaires with listening comprehension scores to assess whether their reflections matched performance. Results showed listening comprehension scores were higher for context-rich lessons and that learners preferred this approach.
\end{abstract}

\section{The Research Aims}

The project aimed to explore practical values of richly contextualised lesson resources and whether they improved listening comprehension. An additional consideration was how the learners responded to context-rich materials.

\section{Why the Problem is Important}

From a pedagogical perspective it would be helpful to clarify effects of context-rich lead in segments to listening comprehension, the perceptions of learners and the potential trade-off in lesson preparation time and effective teaching. Providing appropriate scaffolding and engaging materials are included under effective teaching.

\section{The Context}

The participants were a group of fifteen upper intermediate students, two Korean and thirteen Thai nationals aged between fourteen and fifteen. Their course book was adequate, but grammar based and not particularly engaging. Learners were surveyed for a range of topics they would be interested in studying in English, incorporating language points from their course book. Making listening challenging and enjoyable has been problematic, which led to using web-based materials from video broadcasting sites (e.g., http://www.youtube.com),

Language Education in Asia, 2011, 2(2), 257-267. http://dx.doi.org/10.5746/LEiA/11/V2/I2/A08/Morley 
podcasting sites (e.g., http://www.breakingnewsenglish.com), and stock photography sites (e.g., http://www.corbisimages.com).

\section{Literature Relating to Context \\ Support for Enhancing Contextual Richness}

Brown (1986) argued that materials writers and teachers mistakenly assume when learners of English experience difficulties with listening input these difficulties arise from language deficits which ". . . would arise even if he or she were presented with the same material in the mother tongue" (p. 284). It is the presentation of material that concerns this project. In lessons for listening texts, spending an initial period on pre-listening activities relating to context and emphasising the relationship between noticing language and its subsequent emergence in speech facilitates noticing. If supported by familiar or well-contextualised materials, cognitive processing loads placed on learners are reduced (Richards, 2005, p. 87).

Context is central to cognitive processing and activating schemata (background knowledge). Anderson and Lynch (1988) proposed a psychological model of listeners as limited processors with finite input processing capacities. With this model highlighting listener limitations, implications for establishing a supportive pre-listening context are clear. More cognitive capacity being used for interpreting context means less capacity remains available for noticing language. This aspect of noticing is relevant as learners are increasingly asked to notice language in natural texts rather than explicitly focusing on language points. To address this, Cameron (2001) suggested using familiar stories that provide context and reduce processing demands as familiarity with plot and characters enables learners to spend more time on noticing aspects of language.

Therefore, enhanced context may help learners achieve more, which supports Bruner's concept of scaffolding. Apart from facilitating noticing language, spending an appropriate time establishing context helps students listen more naturally. Underwood's (1989) position on teaching without establishing context is that going directly into a listening text deprives learners of opportunities to use their natural listening skills, as listeners ordinarily match what they hear with their prior experiences or expectations.

Participants in this project are learning English through a variety of topics and specific cultural settings, such as "Festivals" which includes bull running in Spain. These Asian learners have no prior experience of this aspect of festivals. This type of contextual culture gap is an ongoing issue in Asia as learners predominantly use Eurocentric course materials. This view is supported by Anderson and Lynch (1988), who state that it is often not linguistic ability holding learners back, but lack of prior experience or contextual knowledge. Rost (1994) further supports allocating time to context building; this is especially relevant to young learners and cross-cultural factors. In regard to bridging inferences, the author suggests that listeners usually rely on experience of similar circumstances to guide them and tend to assume that any missing information will closely resemble the normal state of affairs. As this tendency is based on life experience, young learners are disadvantaged due to having less broad life experiences to support making bridging inferences and are likely to benefit from contextual support.

\section{Arguments Challenging the Use of Contextual Support}

Evidence relating to enhancing context is not all supportive. When discussing the effects of supportive visuals in language testing, Grinther (2002) questions whether positive effects on performance are related to language proficiency. Proficiency is relevant because the most noticeable improvements have occurred with lower level learners. This difference in 
performance between learner levels suggests other cognitive factors are involved when additional contextual support is introduced. For example, individuals who are not skilled at generating mental images will benefit more from visual aids. However, those well versed in this skill tend to show signs of reduced listening performance, which could be due to visual interference. The author also suggests learners with low levels of spatial ability find holding and processing images in memory problematic. Therefore, this strategy might be best applied with individual learners who have lower spatial abilities and are experiencing difficulties.

Additional processing load could be created unintentionally by presenting text and images together. Combining text and images can cause this additional workload, because attention then has to be split between the two modalities. Subsequently, images with accompanying visual presentation of a text can overload visual attention and impair performance. An example would be reading the news captions on $\mathrm{CNN}$ while trying to listen to the newsreader.

\section{Methodology}

Data collection was undertaken by administering questionnaires eliciting learners' opinions on their listening skills and delivering four lessons that generated comparative data.

\section{Four Lessons}

Lessons 1 and 3 were context-rich, and Lessons 2 and 4 were context-poor. All lessons featured listening passages from Breaking News English (http://www.breakingnewsenglish.com) and accompanying comprehension gap-fill exercises. Follow-up questionnaires on the listening experience were administered immediately after the listening comprehension exercises. Listening comprehension scores were collated and a post-study questionnaire administered to explore attitudes to context-rich and context-poor lessons. The lessons appear in order of presentation.

Lesson 1 - Context-Rich: Cartoons. A forty-minute topic lead-in culminated in the listening text. Learners brainstormed cartoon characters, discussed cartoons and ideas for using them in education, viewed celebrities talking about favourite cartoons, and watched a clip of Wallace \& Gromit before moving on to the listening. From this stage, materials were presented consistently across the lesson series the following stages: presenting the news headline, true or false prediction about the listening content based on the headline, listening with accompanying comprehension gap-fill played twice after which learners completed postlistening questionnaires.

Lesson 2 - Context-Poor: Celebrities. A very brief lead in was used via the headline "Paris Hilton Returns to Jail" with a short true or false prediction exercise. Learners listened to the text twice while completing the accompanying comprehension gap-fill. The post listening questionnaire was completed.

Lesson 3 - Context-Rich: Love. This lesson followed the same outline as context-rich Lesson 1.

Lesson 4 - Context-Poor: Festivals. Lesson 4, on the Carnival in Rio de Janeiro, Brazil, followed the same pattern as context-poor Lesson 2. As this was the final lesson in the series, the post-study questionnaire was given while the experience was still fresh. 


\section{Triangulation and Criterion Referencing}

The project utilised triangulation, suggested by Cohen, Manion, \& Morrison (2000), by focusing on data from a variety of perspectives, ranging from qualitative evidence from learners' ideas about their listening skills, their impressions of how the listening part of the lesson worked for them, to a post-study questionnaire asking for reflection on the lessons and materials. Quantitative data was collected from listening comprehension gap-fill scores and collated to explore differences in performance between context-rich and context-poor lessons.

Criterion referencing was used; referencing focuses on individual learning progress and improvement (Cohen et al., 2000). Therefore, comparison between participants was not considered, as the intention was to describe how individual learners responded to controlled changes in contextual support.

\section{Results}

\section{Learners' Perceptions of Listening Abilities}

Table 1 below shows the learners' rating of aspects of listening ( $1=$ strongly disagree, $2=$ disagree, 3 = neither agree nor disagree, $4=$ agree, $5=$ strongly agree), with the majority rating themselves at 3 and above. Importantly for this study, fifty percent selected 4 (agree) on the item, "If I don't know about the topic, listening is more difficult."

Table 1

Pre-Research Listening Skills Survey

\begin{tabular}{|c|c|c|c|c|c|}
\hline & $\begin{array}{l}\text { Rate } 1 \\
\text { Strongly } \\
\text { disagree }\end{array}$ & $\begin{array}{l}\text { Rate } 2 \\
\text { Disagree }\end{array}$ & $\begin{array}{l}\text { Rate } 3 \\
\text { Neither } \\
\text { agree nor } \\
\text { disagree }\end{array}$ & $\begin{array}{l}\text { Rate } 4 \\
\text { Agree }\end{array}$ & $\begin{array}{l}\text { Rate } 5 \\
\text { Strongly } \\
\text { agree }\end{array}$ \\
\hline 1. I am a good listener. & $0 \%$ & $7.70 \%$ & $61.54 \%$ & $30.76 \%$ & $0 \%$ \\
\hline $\begin{array}{l}\text { 2. I enjoy the listening parts of my } \\
\text { English class. }\end{array}$ & $0 \%$ & $0 \%$ & $15.38 \%$ & $61.54 \%$ & $23.07 \%$ \\
\hline $\begin{array}{l}\text { 3. Learning to listen with real life } \\
\text { materials is more important } \\
\text { than using course books. }\end{array}$ & $0 \%$ & $0 \%$ & $15.38 \%$ & $46.15 \%$ & $38.46 \%$ \\
\hline $\begin{array}{l}\text { 4. I like to listen to topics I know } \\
\text { about. }\end{array}$ & $0 \%$ & $0 \%$ & $15.38 \%$ & $53.84 \%$ & $30.76 \%$ \\
\hline $\begin{array}{l}\text { 5. If I don't know about a topic, I } \\
\text { like to practice before listening. }\end{array}$ & $0 \%$ & $15.38 \%$ & $61.53 \%$ & $23.07 \%$ & $0 \%$ \\
\hline $\begin{array}{l}\text { 6. If I don't know about the topic, } \\
\text { listening is more difficult. }\end{array}$ & $0 \%$ & $15.38 \%$ & $23.07 \%$ & $53.84 \%$ & $7.69 \%$ \\
\hline $\begin{array}{l}\text { 7. I can listen for overall meaning } \\
\text { well. }\end{array}$ & $0 \%$ & $15.38 \%$ & $69.23 \%$ & $15.38 \%$ & $0 \%$ \\
\hline 8. I can listen for detail well. & $0 \%$ & $23.07 \%$ & $46.15 \%$ & $30.75 \%$ & $0 \%$ \\
\hline
\end{tabular}

Note. $n=13$

\section{Context-Rich Lessons 1 and 3}

The majority found the listening texts easy to understand in both context-rich lessons, with $58.33 \%$ and $33.33 \%$ rating themselves at 3 (neither agree nor disagree) and 4 (agree), respectively, for Question 1 in Table 2 below. 
Table 2

Post-Lesson Survey Results for Context-Rich Lesson 1

\begin{tabular}{|c|c|c|c|c|c|}
\hline & $\begin{array}{l}\text { Rate } 1 \\
\text { Strongly } \\
\text { disagree }\end{array}$ & $\begin{array}{l}\text { Rate } 2 \\
\text { Disagree }\end{array}$ & $\begin{array}{l}\text { Rate } 3 \\
\text { Neither } \\
\text { agree nor } \\
\text { disagree }\end{array}$ & $\begin{array}{l}\text { Rate } 4 \\
\text { Agree }\end{array}$ & $\begin{array}{l}\text { Rate } 5 \\
\text { Strongly } \\
\text { agree }\end{array}$ \\
\hline $\begin{array}{l}\text { 1. It was easy to understand the } \\
\text { listening. }\end{array}$ & $0 \%$ & $0 \%$ & $58.33 \%$ & $33.33 \%$ & $8.33 \%$ \\
\hline $\begin{array}{l}\text { 2. I felt confident during the } \\
\text { listening. }\end{array}$ & $0 \%$ & $8.33 \%$ & $75.00 \%$ & $0 \%$ & $16.66 \%$ \\
\hline $\begin{array}{l}\text { 3. I felt relaxed during the } \\
\text { listening. }\end{array}$ & $0 \%$ & $8.33 \%$ & $50.00 \%$ & $25.00 \%$ & $16.66 \%$ \\
\hline $\begin{array}{l}\text { 4. I felt well prepared and ready to } \\
\text { listen about the topic. }\end{array}$ & $0 \%$ & $8.33 \%$ & $50.00 \%$ & $25.00 \%$ & $16.66 \%$ \\
\hline $\begin{array}{l}\text { 5. I needed more preparation time } \\
\text { to listen well. }\end{array}$ & $8.33 \%$ & $8.33 \%$ & $33.33 \%$ & $41.46 \%$ & $8.33 \%$ \\
\hline $\begin{array}{l}\text { 6. My test score was affected by } \\
\text { how familiar I was with the } \\
\text { topic. }\end{array}$ & $0 \%$ & $16.66 \%$ & $25.00 \%$ & $33.33 \%$ & $25.00 \%$ \\
\hline
\end{tabular}

Note. $n=12$

\section{Context-Poor Lessons 2 and 4}

Table 3 below demonstrates differences between context-poor lessons, indicating that learners felt less confident and relaxed when materials were presented with less contextual support.

This is supported by evidence from Question 6, "My test score was affected by how familiar I was with the topic." In Lesson 1, 25\% chose 5 (strongly agree); in Lesson 4, this declined to $7.69 \%$.

\section{Table 3}

\section{Post-Lesson Survey Results for Context-Poor Lesson 4}

\begin{tabular}{|c|c|c|c|c|c|}
\hline & $\begin{array}{l}\text { Rate } 1 \\
\text { Strongly } \\
\text { disagree }\end{array}$ & $\begin{array}{l}\text { Rate } 2 \\
\text { Disagree }\end{array}$ & $\begin{array}{l}\text { Rate } 3 \\
\text { Neither } \\
\text { agree nor } \\
\text { disagree }\end{array}$ & $\begin{array}{l}\text { Rate } 4 \\
\text { Agree }\end{array}$ & $\begin{array}{l}\text { Rate } 5 \\
\text { Strongly } \\
\text { agree }\end{array}$ \\
\hline $\begin{array}{l}\text { 1. It was easy to understand the } \\
\text { listening. }\end{array}$ & $0 \%$ & $30.76 \%$ & $30.76 \%$ & $38.46 \%$ & $0 \%$ \\
\hline $\begin{array}{l}\text { 2. I felt confident during the } \\
\text { listening. }\end{array}$ & $0 \%$ & $23.07 \%$ & $53.84 \%$ & $23.07 \%$ & $0 \%$ \\
\hline $\begin{array}{l}\text { 3. I felt relaxed during the } \\
\text { listening. }\end{array}$ & $0 \%$ & $23.07 \%$ & $46.15 \%$ & $23.07 \%$ & $7.69 \%$ \\
\hline $\begin{array}{l}\text { 4. I felt well prepared and ready to } \\
\text { listen about the topic. }\end{array}$ & $0 \%$ & $0 \%$ & $53.84 \%$ & $30.76 \%$ & $15.38 \%$ \\
\hline $\begin{array}{l}\text { 5. I needed more preparation time } \\
\text { to listen well. }\end{array}$ & $0 \%$ & $15.38 \%$ & $61.53 \%$ & $23.07 \%$ & $0 \%$ \\
\hline $\begin{array}{l}\text { 6. My test score was affected by } \\
\text { how familiar I was with the } \\
\text { topic. }\end{array}$ & $0 \%$ & $7.69 \%$ & $53.84 \%$ & $30.76 \%$ & $7.69 \%$ \\
\hline
\end{tabular}

Note. $n=13$ 


\section{Listening Comprehension Scores for Context-Rich and Context-Poor Lessons}

Table 4 below demonstrates two trends: context-rich lessons produced higher listening comprehension scores overall and the performance of high- and low-scoring learners remained reasonably consistent across the four lessons.

Table 4

Listening Scores Across the Four Lessons

\begin{tabular}{|l|c|c|c|c|}
\hline Learner & $\begin{array}{c}\text { Lesson 1 } \\
\text { context-rich }\end{array}$ & $\begin{array}{c}\text { Lesson 2 } \\
\text { context-poor }\end{array}$ & $\begin{array}{c}\text { Lesson 3 } \\
\text { context-rich }\end{array}$ & $\begin{array}{c}\text { Lesson 4 } \\
\text { context-poor }\end{array}$ \\
\hline 1 & Absent & $0 \%$ & $58 \%$ & $27 \%$ \\
\hline 2 & $47 \%$ & $14 \%$ & $33 \%$ & $27 \%$ \\
\hline 3 & $67 \%$ & $7 \%$ & Absent & $0 \%$ \\
\hline 4 & $86 \%$ & $50 \%$ & Absent & $55 \%$ \\
\hline 5 & $71 \%$ & $0 \%$ & $75 \%$ & $9 \%$ \\
\hline 6 & $50 \%$ & $7 \%$ & $50 \%$ & Absent \\
\hline 7 & $88 \%$ & $43 \%$ & $92 \%$ & $64 \%$ \\
\hline 8 & $29 \%$ & Absent & $42 \%$ & $27 \%$ \\
\hline 9 & $50 \%$ & $0 \%$ & $33 \%$ & $0 \%$ \\
\hline 10 & $71 \%$ & $0 \%$ & $33 \%$ & Absent \\
\hline 11 & $71 \%$ & $14 \%$ & Absent & $18 \%$ \\
\hline 12 & $75 \%$ & $7 \%$ & $83 \%$ & $45 \%$ \\
\hline 13 & $76 \%$ & $0 \%$ & $50 \%$ & Absent \\
\hline 14 & Absent & $7 \%$ & $83 \%$ & $45 \%$ \\
\hline 15 & Absent & $7 \%$ & Absent & $27 \%$ \\
\hline
\end{tabular}

Post-Project Questionnaire: Opinions on Relevance, Value, and Effectiveness

Table 5 shows ratings trending positively towards Responses $C$ and D, indicating learners found context-rich lessons helpful.

\section{Table 5}

\section{Follow-Up Questionnaire: Reflection on the Lessons}

1.Teaching with video clips and help with vocabulary was

\begin{tabular}{|l|r|}
\hline A) Unhelpful & $0 \%$ \\
\hline B) Neutral & $15.38 \%$ \\
\hline C) Improved my listening a little & $46.15 \%$ \\
\hline D) Improved my listening a lot & $38.46 \%$ \\
\hline
\end{tabular}

Note. $n=13$

Table 6 below shows this positive trend was further supported by responses to Item 2 as $76.92 \%$ considered images and video clips helped listening comprehension.

\section{Table 6}

\section{Responses to Item 2}

\begin{tabular}{|l|c|c|c|}
\hline $\begin{array}{l}\text { 2. Video clips and pictures before listening help me understand } \\
\text { more. }\end{array}$ & $\begin{array}{c}\text { True } \\
76.92 \%\end{array}$ & $\begin{array}{c}\text { Neutral } \\
23.07 \%\end{array}$ & $\begin{array}{c}\text { False } \\
0 \%\end{array}$ \\
\hline
\end{tabular}

Note. $n=13$ 
Table 7 demonstrates that Item 6 indicates learners perceive contextualising materials as adding value to their course.

Table 7

\section{Responses to Item 6}

\begin{tabular}{|l|c|c|c|}
\hline 6. Using video and pictures adds quality to my English course. & True & Neutral & False \\
\hline
\end{tabular}

Note. $n=13$

\section{Summary}

Overall, results reflected trends indicated by supporting literature as listening comprehension scores for context-rich lessons were over $50 \%$ higher in many cases. Learners also responded favourably to context-rich materials with $76.92 \%$ indicating they thought visual support helped them understand more and $38.46 \%$ stating that visual and vocabulary support improved their listening a lot.

\section{Analysis and Discussion}

Results indicate correlation between context-rich environments and improved listening comprehension. However, one weakness highlighted by Mayer and Gallini (1990) is that the effects of multimedia are stronger for subjects without prior knowledge of the topic, but barely noticeable for those with it, indicating a project design weakness. Apart from that factor which may have influenced the degree of change in listening comprehension, the crucial point; is that Asian learners often have very different cultural experiences and expectations which are not well represented by globally published materials. This would be even more relevant for younger learners with less life experience to draw on and potentially makes them ideal beneficiaries for multi-media contextual support. Therefore, while the Upper Intermediate group showed listening comprehension improvements relating to context-rich lessons, a lower level group may have demonstrated more significant changes, as Grinther (2002) suggests lower proficiency groups gain more benefits from context-rich environments.

Considering whether preparation time spent on collecting materials to enhance contextual support is well spent; learners responded positively towards context-rich lesson contents. While this is an affective factor, (relating to emotion and motivation) its value as a learningsupport tool should not be underestimated, as engaging motivating lessons foster a positive attitude towards learning which can carry forward to future lessons. Again, younger learners, who rely more on environmental context and learn best from their immediate surroundings might benefit more than older groups who are more comfortable with abstract concepts.

\section{Conclusions}

Learners' listening performance definitely improved during context-rich lessons, confirming evidence from supporting literature. Learners expressed a preference for this type of lesson; therefore, for pedagogical and affective reasons, additional time sourcing materials to provide additional context is time well spent.

However, the evidence supporting analysis should not be taken at face value, as texts were not graded for difficulty. On reflection, context-poor lessons required learners to process more difficult phrases and collocations. Rost (1994) discusses degrees of difficulty relating to input and complexity of information. Context-poor texts would be rated as high difficulty because they lack repetition or redundancy and are informationally dense, as news items tend to be. 
The project would have more credibility if it had incorporated Grinther's (2002) suggestion that lower proficiency levels benefit more from contextual support. This aspect needs addressing through comparative studies with upper intermediate and elementary-level learners.

\section{Recommendations}

This study involved higher-level learners, but the methods have since been used with elementary-level groups. The only noticeable difference was the need to allow additional processing time for elementary-level learners to formulate and discuss their ideas in English as they have fewer linguistic resources to draw on. In terms of benefit, the visual input and contextual examples are likely to provide a significant amount of non-verbal support, although further study is needed to fully evaluate this. The author's preference would be to increase the amount of contextual support for lower-level groups.

As discussed earlier, a large body of evidence supports allocating significant amounts of time to pre-listening activities, whatever the learners' level, to activate pre-existing knowledge and create expectations or predictions of what they are likely to hear. In this way, listening-text topics are able to fit into existing cognitive maps, which supports processing and decoding. Therefore, time spent preparing learners to listen is repaid by an improved listening comprehension experience.

\section{Author Note}

Nick Morley, freelance teacher and trainer.

Correspondence concerning this article should be addressed to Nick Morley. E-mail: xyiq@yahoo.com. Skype ID: nick.morley111 


\section{References}

Anderson, A., \& Lynch, T. (1988). Listening. Oxford, England: Oxford University Press.

Brown, G. (1986). Investigating listening in context. Applied Linguistics, 7(3), 285-302. http://dx.doi.org/10.1093/applin/7.3.284

Cameron, L. (2001). Teaching English to young learners. Cambridge, England: Cambridge University Press.

Cohen, L., Manion, L., \& Morisson, K. (2000). Research methods in education. London, England: Routledge Falmer.

Grinther, A. (2002). Context and content visuals and performance on listening comprehension stimuli. Language Testing, 19, 133-166. http://dx.doi.org/10.1191/0265532202lt225oa

Mayer, R. E., \& Gallini, J. K. (1990). When is an illustration worth a thousand words? Journal of Educational Psychology, 82(4), 715-726. http://dx.doi.org/10.1037/0022-0663.82.4.715

Richards, J. C. (2005). Second thoughts on teaching listening. RELC Journal, 36(1), 85-92. http://dx.doi.org/10.1177/0033688205053484

Rost, M. (1994). Introducing listening. London, England: Penguin.

Underwood, M. (1989). Teaching listening. Harlow, England: Longman. 


\section{Appendix 1 \\ A Practical Example}

The following example demonstrates that globally published or Eurocentric course materials are not always contextually relevant for Asian learners because the materials may not reflect their interests or life experiences. It is still possible to adapt how listening is approached and ultimately use these materials effectively. This can be achieved by considering how the materials might be presented in the light of present knowledge, contextualised through the use of video or images and adapted to local settings.

The course materials, which were produced in Europe, featured a listening on the topic "Festivals" with bull running in Pamplona, Spain as the listening text. The learners had no prior knowledge of this event, so it was presented in the following way: learners brainstormed and pooled their existing vocabulary relating to festivals by using the prompts, "When you think of Songkran (Thai New Year) and Seol-nal (Korean Lunar New Year), what do you think of, how do you feel, and what do you do?" The learners then added these ideas as well as vocabulary to mind-maps. Having activated learners' schemata (existing background knowledge and expectations relating to the topic of festivals), the next step involved watching a YouTube video of the Pamplona Bull Run while underlining any relevant ideas or vocabulary from their mind-maps. Learners then worked in pairs to discuss differences between their local festivals and bull running before sharing their ideas with a wider audience. At this point, additional language was elicited and provided to support a fuller description of the Spanish festival, especially regarding the differences in terms of family-centred versus individual risktaking activities, types of emotion, and danger. Learners were then more fully prepared to make the most of the course listening text as the types of event, actions, and narratives would not be unfamiliar and would allow learners to work with existing expectations about the event, its cultural relevance, and associated activities. 


\section{Appendix 2}

Learners' Views

Post-listening interviews revealed preferences correlating with learners' listening abilities.

Regarding context-poor Lesson 2, Learner 1, a capable listener, seemed to enjoy the challenge, whereas Learner 2, who is less skilled, found the lesson difficult.

Researcher: Can you tell me how you found the listening exercise this week, because there was no video to prepare for it and no vocabulary exercises to get ready for it?

Learner 1: I think it is a bit hard, but it is not too hard. We should get like this every week, it's not too easy.

Learner 2: I think it's very difficult because I don't know many words in vocabulary.

After context-rich Lesson 3, Learner 3 stated that additional contextual support was helpful.

Researcher: What's the best way to do the listening - with video and activity before, or go straight to the listening and why?

Learner 3: I think to do some video and to do an activity before is better . . . So it makes it easier to do another thing.

Learner 2's comment that the context-poor lesson was difficult because she did not know much of the vocabulary is significant. This is an area which context-rich materials are able to address before listening takes place by providing more listening resources. 